Published in the Journal of Bahá'í Studies Vol. 12, number 1/4 (2002)

(C) Association for Bahá'í TM Studies 2002

\title{
The Three Stages of Divine Revelation
}

\author{
Guy Sinclair
}

\begin{abstract}
In God Passes By, Shoghi Effendi briefly summarizes the contents of Bahá'u'lláh's Kitáb-i-Íqán, stating (inter alia) that the Kitáb-i-Íqán "adumbrates and distinguishes between the three stages of Divine Revelation." This paper seeks to explore the meaning of this short phrase, by discussing what Shoghi Effendi means by "Divine Revelation" and by locating the three stages in the Íqán itself. The paper then sketches some doctrines of Sufi philosophers which provide important background to understanding the significance of Bahá'u'lláh's three stages, and attempts to articulate one understanding of the passage in the Kitáb-i-Íqán, read together with Shoghi Effendi’s interpretation.
\end{abstract}

\begin{abstract}
Résumé
Dans Dieu passe près de nous, Shoghi Effendi résume brièvement le contenu du Kitáb-i-Íqán de Bahá'u'lláh. Il déclare, entre autres, que le Kitáb-i-Î́án «laisse entrevoir et fait la distinction entre les trois stades de Révélation divine». Le présent exposé tente d'explorer la signification de ce bref énoncé en examinant ce que Shoghi Effendi entend par «Révélation divine», et en repérant ces trois stades dans l'oeuvre elle-même. Puis, l'auteur esquisse certaines doctrines philosophiques soufies, les quelles nous offrent un cadre contextuel nous permettant de comprendre la signification des trois étapes dont parle Bahá'u'lláh. Il propose enfin une explication du passage dans le Kitáb-i-Íqán, à la lumière de l'interprétation qu'en fait Shoghi Effendi.
\end{abstract}

\section{Resumen}

En Dios Pasa, Shoghi Effendi resume en breve el contenido del Kitáb-i-Íqán de Bahá'u'lláh, comentando (inter alia) que el Kitáb-i-Íqán "vislumbra y distingue entre las tres etapas de la Revelación Divina." Este ensayo intenta explorar el significado de esta corta frase mediante la discusión de lo que quiere dar a entender Shoghi Effendi por "Revelación Divina," localizando a la vez las tres etapas en el mismo Íqán. El ensayo pasa entonces a trazaralgunas doctrinas de filósofos sufíes que proveen fondo importante para la comprensión del significado de las tres etapas de Bahá'u'lláh, e intenta articular sólo un entendimiento del pasaje en el Kitáb-i-Íqán, leído junto con la interpretación de Shoghi Effendi.

\section{Introduction}

As Guardian of the Bahá'í Faith, Shoghi Effendi inherited from 'Abdu'l-Bahá the function of interpreting the Revelation of Bahá'u'lláh. He exercised this function through the plans he made and the projects he executed, in the unnumbered letters he addressed to institutions, communities, and individuals, in his exemplary translations of the Sacred Writings of this Dispensation, and in dozens of major communications, including his World Order letters, The Advent of Divine Justice, and The Promised Day Is Come. God Passes By, his one book per se-ostensibly a historical overview of the first Bahá'í century—represents a major contribution to his avowed task of systematizing the Bahá'í teachings. ${ }^{1}$

In Chapter 8 of God Passes By, Shoghi Effendi summarizes the rise in the fortunes of the Faith in the latter part of Bahá'u'lláh's Baghdad exile; he dwells upon Bahá'u'lláh's prodigious literary output during this period and singles out the Kitáb-i-Íqán for special attention. In a paragraph beginning, "Within a compass of two hundred pages," Shoghi Effendi summarizes the contents of that Book. In doing so, he demonstrates his particular genius for synthesis and provides the Bahá'í world with an indispensable guide to the study of Bahá'u'lláh's Book of Certitude. One short phrase of Shoghi Effendi's summary provides the topic for this paper, and it is worth turning to the particular words the Guardian uses. The Kitáb-i-Íqán, he states unconditionally, "adumbrates and distinguishes between the three stages of Divine Revelation" (139). What Shoghi Effendi means by "the three stages of Divine Revelation" is not immediately apparent, even to one who has studied the Kitáb-i-Íqán in some depth. The reader will search in vain for the phrase itself in the text of that Book, since nowhere is there an explicit reference to "three stages" of anything. It is therefore intriguing that the Guardian of the Bahá'í Faith has nonetheless identified this as one of the major themes of the Kitáb-i-Íqán.

This paper can only scratch the surface of this endlessly fascinating subject. I will begin by discussing what Shoghi Effendi means by "Revelation," and by locating the three stages of divine revelation in the Kitáb-i-Íqán. I will then sketch some doctrines of Islamic mystical (Sufi) philosophers, which provide important background to 
understanding the significance of Bahá'u'lláh's three stages. Finally, I will draw some preliminary comparisons between the models of divine revelation set out by Bahá'u'lláh and those offered by certain adherents of the school of Ibn 'Arabí, and will attempt to articulate one understanding of the relevant passage from the Íqán, read together with Shoghi Effendi’s interpretation in God Passes By.

\section{Locating the Three Stages in the Kitáb-i-Íqán}

We can find some clues as to what Shoghi Effendi means by the term "Divine Revelation" by searching his other writings and translations for similar terms. In Bahá'u'lláh's Epistle to the Son of the Wolf, which Shoghi Effendi also translated, we find this suggestive reference: "Briefly, there hath been revealed in the Kitáb-i-Íqán . . . concerning the Presence [liqá] and Revelation [tajallí] of God that which will suffice the fair-minded" (119). The term tajalli is commonly understood in Islam, and especially in Sufism, as referring to the self-manifestation of God, principally in and through His act of bringing the cosmos into being. We will return to Sufi beliefs on this matter shortly. Suffice it to say for the time being that by tajalli Sufis do not mean primarily revelation in the sense of Scripture, or even in the sense of the appearance of the Manifestation of God. Rather, they view the whole of Creation-including both the visible and the invisible worlds—as revealing God's Names and Attributes.

Turning to the text of the Book of Certitude with this understanding of the meaning of "Revelation," the three stages are more easily located. In the second part of the Kitáb-i-Íqán, Bahá'u'lláh takes as one of His themes the explanation of the "Day of Resurrection." In particular, He unfolds the meaning of the "Presence of God" (liqá'u'lláh), a phrase which is used in the Qur'án. In doing so, He dismisses two possible interpretations and settles upon a third (Kitáb-i-Íqán 89-91). He first denies that the eschatological promise of attainment to the Presence of God could refer to the reflection of the divine qualities in all things, since this is always available and is not confined to the "last days." Next, Bahá'u'lláh considers the possibility that the "Presence of God" could refer to a revelation that takes place eternally in the knowledge of God; this too He dismisses, for the simple reason that such a revelation is beyond the reach of anyone but God Himself and therefore could not be the subject of a divine promise to humankind. Finally, He definitely asserts that by the "Presence of God" is meant attainment unto the "primal and original manifestation of God" in His Prophets and Chosen Ones. In each of these three instances, Bahá'u'lláh employs the term tajalli in a particular way.

To summarize, Bahá'u'lláh describes in total three different kinds of divine revelation, one of which $\mathrm{He}$ identifies with the promises of attainment to the divine presence that are recorded in the Holy Books. Shoghi Effendi interprets this passage as adumbrating three stages of revelation; how this is so, and why this is significant, will be explored below. For now, in the order in which they appear in the text, the three kinds of revelation are (1) The "Universal Revelation" (tajallíy-i- 'ám) of God's signs in all things; (2) The "Specific Revelation of God" (tajallíy-ikháss), or the "Most Holy Outpouring" (fayd-i-aqdas), which is in the Essence itself and has been eternally in the divine Knowledge; (3) The "Secondary Revelation of God" (tajallíy-i-thání), or the "Holy Outpouring" (fayd-imuqaddas), which is in the realm of the original and primal manifestation and is confined to the Prophets and Chosen Ones of God. ${ }^{2}$

\section{The Self-Revelation of God in Sufi Thought}

In the passages just cited, Bahá'u'lláh pointedly refers to two terms used by "certain Sufis." In order to appreciate the significance of the three stages of divine revelation as adumbrated by Bahá'u'lláh, some understanding of these Sufi ideas is necessary.

\section{The Notion of Emanation (Fayd)}

The two Sufi terms to which Bahá'u'lláh refers are "the Most Holy Outpouring" (fayd-i-aqdas) and the "Holy Outpouring" (fayd-i-muqaddas), and He relates these explicitly to the notions of the "specific Revelation of God" and the "Secondary Revelation of God," respectively. Both of these terms denote stages in a larger process of emanation ("outpouring" in Shoghi Effendi's translation), which is how certain Sufis conceive of the process of creation.

Put another way, these Sufis believe that the very nature of God requires, or at least results in, a creation, and that creation proceeds from the Godhead through a process of emanation. This idea can be traced to the formulations of Neoplatonism, especially in the writings of Plotinus, who described the emanation of a series of hypostases: the One, the Intellect, and the Soul. The wide-ranging influence of Neoplatonic emanationism on thought in the Islamic world, and in particular on philosophers and mystics such as al-Kindí, al-Fárábí, Ibn Síná and Suhrawardí, is well-established.3 Though there are significant differences, as we shall see, this conception of creation is similar to that described by 'Abdu'l-Bahá in, for example, Some Answered Questions (chapters 53, 54, and 83 in particular). 
The notion of fayd-and the use of the terms fayd-i-aqdas and fayd-i-muqaddas-was developed extensively in the writings of ash-Shaykh al-Akbar (the "Great Shaykh"), Muhyi'd-Dín Ibn "Arabí (d. 1240 C.E.) and the "Akbarian" school or stream of theology and mysticism that built upon his work. ${ }^{4}$ Ibn "Arabí's writings on the subject rely heavily on his interpretation of a "holy tradition" (hadith qudsî) which states, in the Voice of God: "I was a Hidden Treasure and desired to be known. Therefore I created the Creation that I might be known." ${ }^{5}$ The Bahá'í writings abound with allusions to this tradition, and 'Abdu'l-Bahá wrote a highly significant commentary on it while He was still a teenager in Baghdad. ${ }^{6}$ The point to note here, however, is that Ibn 'Arabí and other Sufi teachers have understood this tradition as alluding to stages in the self-manifestation of God, beginning with His being a Hidden Treasure and resulting finally in the act of creation.

\section{The Most Holy Emanation/Outpouring: Fayd-i-aqdas}

According to Izutsu, Ibn 'Arabí distinguishes between two major stages in the process of fayd (154). It is important to keep in mind that Ibn 'Arabí did not intend to suggest that the stages of divine revelation took place consecutively, one and then the other; rather, we should imagine them all happening simultaneously and eternally. Ibn "Arabí's first stage, called fayd-i-aqdas, corresponds to the "movement" of God from being a Hidden Treasure to His wishing to be known. Using the terminology of the Sufis, God "leaves" the state of pure and undifferentiated Unity, or ahadiyya, and then "enters" the state of a Oneness which is potentially plurality, or wáhidyya. In the tradition cited above, the state of ahadíyya is described as God being a "Hidden Treasure." The term wáhid, from which derives wáhidíyya, is the active participle of ahad. As soon as the verb "desired" or "loved" (ahbabtú) is introduced - when God loves to be known - there is movement from the state of ahadíyya to that of wáhidiyya. Fayd-i-aqdas has thus been described as "the first appearance of a foreboding of 'existence.' . . [which] means nothing else than the Absolute becoming conscious of itself as "existence" or as "the self-manifestation of the Absolute to itself" (Izutsu 119). This stage in the process of divine revelation is likewise described as that stage during which "the Absolute becomes conscious of itself as potentially articulated into an infinity of existents" (Izutsu 154).

This "event," which is eternally "occurring" within the Unseen (ghayb), results in the "formation" of the "permanent archetypes" (a yán thábita) in the consciousness of the Absolute. These permanent archetypes are the essential forms of all things in this world, and can be understood as the "appearance" of the Divine Names out of the undifferentiated Unity of ahadíyya. Ibn "Arabí describes the station of ahadíyya as the "Absolute Unknowableness"; the "Universe of the Divine Nature" ('álam al-láhút ); the "universe of nonmanifestation" (lá ta-ayyún); "Pure Ipseity," or "Essence" ( $\underline{d h} a ́ t)$. He further says that "[w]hatever word is used to explain this station is inadequate because at this Presence the Ipseity of God is in Complete Transcendence from everything, because He has not yet descended into the Circle of Names and Qualities. All the Names and Qualities are buried in annihilation in the Ipseity of God" (Ibn 'Arabí 10).

In the station of wáhidíyya, on the other hand, which is entered as a result of the "most holy emanation" (fayd-i-aqdas), the Names of God are articulated and the universe appears in potentia: "This station is ... called the Universe of Names, Fixed Potentialities (a yán thábita), Universe of Quiddities (mahíyya), the Great Isthmus" (Ibn "Arabí 11). Although much more could be said on this subject, the following is a useful summary of the state entered into as a result of fayd-i-aqdas: "On this level, there is as yet nothing existent in actuality. The world itself is not existent. Yet there are dimly discernible the figures of the would-be things. . . . In reality and in themselves, these figures are the content of the Consciousness of the Absolute, and as such, nothing can possibly be more solidly definite and distinct. They are 'realities' (haqá'iq) in the full sense of the word" (Izutsu 155).

\section{The Holy Emanation/Outpouring: Fayd-i-muqaddas}

Ibn 'Arabí identifies a second stage of emanation which he calls fayd-i-muqaddas. In the terminology of the tradition, this is the "movement" from God desiring to be known, to God actually bringing creation into being. Having brought the divine Names into existence, the self-revelatory nature of God "causes the individual things to arise as concrete actualizations of the Names" (Izutsu 121). In other words, the real world or cosmos is brought into being through the diffusion of the permanent archetypes in sensible things, which include the whole realm of contingency: substances, attributes, actions, and events (Izutsu 156). Henry Corbin describes the whole process of fayd in Ibn 'Arabí's thought in the following passage:

The initial Epiphany (tajalli) . . . is twofold: one epiphany takes place in the world of Mystery ('álam al-ghayb), the other in the phenomenal world ('álam al-shahádat). The first is the Epiphany of the Divine Being to Himself and for Himself in the archetypal essences, the eternal hexeities of His Names which aspire towards their concrete Manifestation. This is the sacrosanct Effusion (faydaqdas) in the 
"Presence of the Names" (Hadrat al-Asmá). The second is the Epiphany in the manifest world, that is, in the beings who are the epiphanic (mazhar) forms or receptacles of the divine Names. This is the holy, "hieratic" and "hierophanic" Effusion (fayd-i-muqaddas) which brings to Light those forms which, like mirrors, receive the reflection of the pure divine Essence in proportion to their respective capacities. (195)

This description of the divine self-revelation can be represented and summarized in Figure $1 .^{8}$

\begin{tabular}{c} 
THE WORLD OF MYSTERY \\
Ahadíyya ("I was a Hidden Treasure") \\
Wáhiddíyya ("and desired to be known") \\
\hdashline \\
THE WORLD OF CREATION \\
The created, contingent realm ("Therefore I created the creation") \\
\hline
\end{tabular}

Figure 1. Ibn ‘Arabí's Two Stages of Revelation

\section{Bahá'u'lláh's Cosmogonic Scheme}

In contrast with the two-stage scheme of emanation crudely illustrated in Figure 1, Bahá'u'lláh describes three types of divine revelation in the Kitáb-i-Íqán. Shoghi Effendi interprets the relevant passage in that Book as "adumbrat[ing]" and "distinguish[ing]" between "the three stages of Divine Revelation." If we take seriously the interpretive authority of the Guardian of the Bahá'í Faith, it seems that this short phrase is worth considering in more detail. In particular, Shoghi Effendi specifies that three stages - not simply three types—of divine revelation are distinguished. The word "stages" suggests that there is a particular order and sequence that is followed, that each type of revelation is a successive step in an overarching process. We have seen that at least two modern commentators on Ibn 'Arabí's cosmogony describe a process with two stages. What is the significance of Shoghi Effendi's comment that Bahá'u'lláh distinguishes three?

\section{Tajallíy-i-kháss: The Specific Revelation of God}

The first stage we can compare with Ibn 'Arabí's system is Bahá'u'lláh's tajallíy-i-kháss, the "Specific Revelation of God," which Bahá'u'lláh explicitly identifies with fayd-i-aqdas, the "Most Holy Outpouring" in the terminology of "certain Sufis." Bahá'u'lláh notes that the tajallíy-i-kháss "hath been eternally in the divine Knowledge" (Kitáb-iÍqan 91). This appears to conform to Ibn 'Arabí's characterization of fayd-i-aqdas as being an event in the Divine Consciousness. However, it should be noted that Bahá'u'lláh qualifies His comments with the phrase, "[a]ssuming the truth of this hypothesis," and He goes on to emphasize that no one can attain to or understand the "innermost Essence." Elsewhere, moreover, Bahá'u'lláh indicates that the station of wáhidiyya should be identified with the Manifestations of God: "We testify that He is One [wáhidan] in His Essence [dhá t], One [wáhidan] in His Attributes [sifát]" (Epistle 98). We should be careful, then, about importing any Sufi understanding of fayd-i-aqdas wholesale into the passage from the Kitáb-i-Íqán. ${ }^{9}$

\section{Tajallíy-i-thání: The Secondary Revelation of God}

With regard to the stage of tajallíy-i-thání, the "Secondary Revelation of God," Bahá'u'lláh states that this "primal and original manifestation of God" is indeed "applicable to the world of creation" (Kitáb-i-Íqán 91). Here Bahá'u'lláh appears to depart from the Akbarian scheme we have outlined above, which describes the creation of so-called real things as taking place immediately after the appearance of the Names or permanent archetypes in the Godhead. Bahá'u'lláh affirms that there is yet another stage in the process of divine revelation, and He explains that this stage is confined to God's Prophets and Chosen Ones, "inasmuch as none mightier than they hath come to exist in the world of being" (91). In the passage in question in the Íqán, Bahá'u'lláh is making the point that the Presence of God (liqá'u'lláh), promised in the Qur'án, is attainable only through the Prophets. In this connection, the Epistle to the Son of the Wolf states: 
In all the Divine Books the promise of the Divine Presence hath been explicitly recorded. By this Presence is meant the Presence of Him Who is the Day-spring of the signs, and Dawning-Place of the clear tokens, and the Manifestation of the Excellent Names, and the Source of the attributes, of the true God, exalted be His glory. . . . By Presence . . . is meant the Presence of the One Who is His Viceregent amongst men. (Epistle 118)

In the context of our discussion of the self-revelation (tajalli) of God, and of Shoghi Effendi's interpretation of the Íqán passage, however, Bahá'u'lláh is also indicating the role played by the Manifestations of God in the process of creation. It is interesting to consider two more passages from the Kitáb-i-Íqán in this light: "Through Him [the Manifestation of God] all things live, move, and have their being. Through His grace they are made manifest, and unto Him they all return. From Him all things have sprung, and unto the treasuries of His revelation they have all repaired. From Him all created things did proceed, and to the depositories of His law they did revert" (23). And: “. . . all else besides these Manifestations, live by the operation of their Will, and move and have their being through the outpourings of their grace" (66-67).

'Abdu'l-Bahá makes the same point in Some Answered Questions where He differentiates between "the world of God, the world of the Kingdom, and the world of Creation." He then states that "[t]he first emanation from God is the bounty of the Kingdom, which emanates and is reflected in the reality of the creatures" (295). In the same book, He also states that "[t]he first thing [avval] which emanated [sádir] from God [az haqq] is that universal reality [haqiqat-i-kulliyyih], which the ancient philosophers termed the 'First Mind,' [aql-i-avval] and which the people of Bahá call the 'First Will' [mashíyyat-i-avvalíyyih] " (203). The "universal reality" which 'Abdu'l-Bahá refers to here—often called the Primal Will in the Bahá'í writings—is the true reality of the Manifestations of God. ${ }^{10}$

\section{Tajallíy-i- ‘ám: The Universal Revelation of God}

Finally, Bahá'u'lláh describes a third stage of revelation, the Universal Revelation of God (tajallíy-i- 'ám) which, He says, "already existeth in all things." At this stage contingent "things"" are finally brought into existence, as they had in the second stage of the Akbarian scheme described above. Once again, the writings of Bahá'u'lláh refer frequently to this form of revelation, for example:

We have demonstrated that all things are the recipients and revealers of the splendours of that ideal King, and that the signs of the revelation of that Sun, the Source of all splendour, exist and are manifest in the mirrors of beings. Nay, were man to gaze with the eye of divine and spiritual discernment, he will readily recognize that nothing whatsoever can exist without the revelation of the splendour of God, the ideal King. Consider how all created things eloquently testify to the revelation of that inner Light within them. (Kitáb-i-Íqán 90)

[W] hatever is in the heavens and whatever is on the earth is a direct evidence of the revelation within it of the attributes and names of God, inasmuch as within every atom are enshrined the signs that bear eloquent testimony to the revelation of that most great Light. Methinks, but for the potency of that revelation, no being could ever exist. (Kitáb-i-Íqán 65)

Know thou that every created thing is a sign of the revelation of God. Each, according to its capacity, is, and will ever remain, a token of the Almighty. Inasmuch as He, the sovereign Lord of all, hath willed to reveal His sovereignty in the kingdom of names and attributes, each and every created thing hath, through the act of the Divine Will, been made a sign of His glory. So pervasive and general is this revelation that nothing whatsoever in the whole universe can be discovered that doth not reflect His splendor. (Gleanings 184)

We should emphasize that this stage of creation comes "after" the emanation of the reality of the Prophets; the emanation of the cosmos occurs "through" the Manifestation of God. In His commentary on the same tradition which formed the basis of Ibn 'Arabí's thought, 'Abdu'l-Bahá asserts that the words "and so I created the Creation" refer to the shining forth, "with all the limitless Divine Names and Attributes, from the Dawning Place of Creation ... upon and for sake of Possible Being" (Momen 33). This "Dawning Place" is none other than the Manifestation of God. Figure 2 illustrates one possible understanding of the three stages of divine revelation identified by Shoghi Effendi in the Kitáb-i-Íqán, based on the foregoing discussion. I should emphasize that this is only one understanding of what Shoghi Effendi might have meant by his reference to the "three stages" in God Passes By; no doubt much more will be written on this subject in the future, and whatever errors and misunderstandings there are 
in this essay will be corrected. There are inevitable epistemological handicaps in any discussion or exploration of the reality of the Prophets, as Bahá'u'lláh indicates Himself in the Íqán: "Human tongue can never befittingly sing their praise, and human speech can never unfold their mystery" (Kitáb-i-Íqán 67). This diagram, and the horizontal lines separating the various divine worlds, are only suggestive and necessarily schematic concerning realms which human minds and souls cannot fathom. ${ }^{11}$

\begin{tabular}{|c|c|}
\hline$\longleftarrow$ & $\begin{array}{l}\text { THE WORLD OF GOD } \\
\text { (“INNERMOST ESSENCE”) } \\
\text { First stage: fayd-i-aqdas / tajallíy-i-kháss } \\
\text { (takes place within the Divine Knowledge?) }\end{array}$ \\
\hline$\longleftarrow$ & $\begin{array}{l}\text { THE WORLD OF COMMAND } \\
\text { (“THE REALM OF THE PRIMAL AND ORIGINAL } \\
\text { MANIFESTATION OF GOD”) } \\
\text { Second Stage: fayd-i-muqaddas / tajallíy-i-thání } \\
\text { (“confined to His Prophets and Chosen Ones") }\end{array}$ \\
\hline$\longleftarrow$ & $\begin{array}{l}\text { THE WORLD OF CREATION } \\
\text { Third stage: tajalliy-i-'ám } \\
\text { ("existeth in all things") }\end{array}$ \\
\hline
\end{tabular}

Figure 2. Bahá'u'lláh's Three Stages of Divine Revelation

\section{Conclusion}

In the Kitáb-i-Íqán, Bahá'u'lláh Himself describes that Book as condensing "all the Scriptures and the mysteries thereof into a brief account," and promises that meditation on its contents will result in discovery of "the mysteries of the Words of God" and apprehension of "whatever hath been manifested by that ideal King" (237). In the course of His argument, ostensibly constructed to convince an uncle of the Báb of his nephew's Prophethood, Bahá'u'lláh canvasses a broad range of themes, unseals the meaning of puzzling scriptural references, and outlines the bases of Bahá'í theology. In the passage we have been considering, He also reveals truths concerning the process of creation and divine self-revelation, and thereby unfolds for us the basic structure of Bahá'í cosmology.

That structure, as represented in the Bahá'í Ringstone Symbol, is essentially tripartite: a "personal God, unknowable, inaccessible, the source of all Revelation, eternal, omniscient, omnipresent and almighty" (Shoghi Effendi 139); the Manifestations of God, in their "station of essential unity" (Bahá'u'lláh, Kitáb-i-Íqán 176); and the worlds of creation, represented at their highest in humanity.12 In the Kitáb-i-Íqán, Bahá'u'lláh describes three types of revelation that together constitute a process of divine self-revelation in stages that parallel these levels-occurring respectively within the unknowable Essence of God, in the projection of the Primal Will (or First Mind) discoverable in the Manifestations, and in all created things. The cosmogonic scheme that we may thus construct from the Íqán, taken together with the interpretations of Shoghi Effendi, thus contrasts in some respects with the Akbarian model of divine self-revelation presented in some places by modern commentators on Ibn 'Arabí, such as Izutsu and Corbin. Bahá'u'lláh has categorically distinguished between three stages in the emanative process: Shoghi Effendi's words are "the three stages of Revelation" (emphasis added). Some similarities and differences between the two models can be seen by placing them side by side in a table (Figure 3).

The passage from the Kitáb-i-Íqán I have presented here thus has implications beyond the discussion of eschatology which is the immediate context in that section of the Book. More work needs to be done in relating Bahá'u'lláh's cosmological and metaphysical teachings to those developed within other religious traditions. Exploring these aspects of Bahá'u'lláh's Revelation will also likely affect our understanding, appreciation, and participation in the process which accompanies and counters the emanation of the cosmos: the "return" of the human soul to its Lord. 


\begin{tabular}{|c|c|}
\hline IBN 'ARABÍ & BAHÁ'U'LLÁH \\
\hline $\begin{array}{l}\text { 1. FAYD. -I-AQDAS (the most holy } \\
\text { emanation) } \\
\text { - Appearance of Divine Names, Archetypes } \\
\text { in the Divine Consciousness (Knowledge) } \\
\text { - ahadíyya } \longrightarrow \text { wáhidíyya }\end{array}$ & $\begin{array}{l}\text { 1. TAJALLÍY-I-KHÁSS; FAYD. -I-AQDAS } \\
\text { (the Specific Revelation of God; the } \\
\text { "Most Holy Outpouring") } \\
\text { - "eternally in the Divine Knowledge" } \\
\text { - "confined to the innermost Essence, unto } \\
\text { which no man can attain" }\end{array}$ \\
\hline & $\begin{array}{l}\text { 2. TAJALLIY-I-THANI ; FAYD-I-MUQADDAS } \\
\text { (the Secondary Revelation of God; the "Holy } \\
\text { Outpouring") } \\
\text { " "applicable to the world of creation" } \\
\text { "in the realm of the primal and original } \\
\text { Manifestation of God" } \\
\text { "confined to His Prophets and Chosen } \\
\text { Ones" }\end{array}$ \\
\hline $\begin{array}{l}\text { 2. FAYD. -I-MUQADDAS } \\
\text { (the holy emanation) }\end{array}$ & $\begin{array}{l}\text { 3. TAJALLIIY-I- 'ÁM (the Universal } \\
\text { Revelation of God) } \\
\text { " "all created things ... testify to the } \\
\text { revelation of that inner Light within them" } \\
\text { " "such a revelation already existeth in all } \\
\text { things" }\end{array}$ \\
\hline
\end{tabular}

Figure 3

\section{Notes}

I acknowledge my great debt to Hooper Dunbar, who encouraged me to explore this topic in the first place. I have benefitted greatly from the detailed and loving advice of Khazeh Fananapazir and John Vahid Brown, and from the early assistance of Behrouz Hedayati and Peyvand Khaleghian. Drafts of this paper were presented at a New Zealand Association for Bahá'í Studies conference in 1998, and at the 'Irfán Colloquium, London, England, 2000. Thanks also are due to the two anonymous reviewers from this journal.

1. See the Foreword to God Passes By, where Shoghi Effendi describes the "evolution in the scope" of the teachings of the Faith, culminating in their being "systematized and universally applied" (xvii).

2. These are also identified as Shoghi Effendi's "three stages of Divine revelation" by Hooper Dunbar in his invaluable Companion to the Study of the Kitáb-i-Íqán (181-83).

For simplicity, the Persian transliteration of these terms will be used throughout this paper even though some of the texts cited are in Arabic.

3. Netton, Alláh Transcendent and "Brethren of Purity"; also see Black; Goodman; and Genequand.

4. Shoghi Effendi recounts that, in a series of interviews with eminent doctors and students, Bahá'u'lláh was able to elucidate and interpret the major work of Ibn 'Arabí, the Futúhát-i-Makkíyyih, to their complete satisfaction and amazement (122-23). Brown and Saiedi have both published important studies on the relationship between Ibn 'Arabí and the Bahá'í teachings. Scholarship on this relationship is complicated by the great variety in Ibn Arabí's own thought, as well as differences among his many followers and interpreters, as Brown notes (3). In this paper, I rely primarily on interpretations of Ibn 'Arabí by modern scholars such as Corbin and Izutsu, whose own relationship to and expositions of Ibn 'Arabí's writings may well be idiosyncratic or overly dependent on the 
views of certain of Ibn Arabí's followers. More scholarship is certainly needed in this regard. It is intriguing, however, to note this reference by Nabíl in The Dawn-Breakers:

In the works of the learned and far-famed Muhyi'd-Dín-i- 'Arabí, many references are to be found regarding both the year of the advent and the name of the promised Manifestation. Among them are the following: "The ministers and upholders of His Faith shall be of the people of Persia." "In His name, the name of the Guardian ["Alí] precedeth that of the Prophet [Muhammad]." "The year of His Revelation is identical with half of that number which is divisible by nine [2520]." (49)

5. Ibn "Arabí actually cites this tradition in a slightly different form, as: "I was a Treasure but was not known. So I loved to be known, and I created the creatures and made Myself known to them. Then they came to know Me" (Chittick, Sufi Path 66).

6. See Shoghi Effendi 241; Momen; Brown 8-13, 19-20.

7. It is necessary to use quotation marks throughout when discussing these ideas, if only to remind the reader that these are efforts to describe a process essentially beyond human comprehension. Bahá'u'lláh explains that God is "immeasurably exalted . . . above the strivings of mortal man to unravel [His] mystery, to describe [His] glory, or even to hint at the nature of [His] Essence" (Gleanings 3-4); human understanding likewise falls short of the Manifestation of God.

8. This diagram is only an attempt to roughly capture the scheme set out by Corbin, taken together with the foregoing discussion. It does not pretend to represent definitively the cosmogonic doctrines of Ibn 'Arabí, which are in any case too complex to be presented here in full. Rather I hope only to sketch an outline of his usage of certain specific terminology as a backdrop to better understanding the meaning of the passage we are examining in the Kitáb-i-Íqán, and the implications of Shoghi Effendi's interpretation of that passage. I refer in this essay to the diagram as illustrating an "Akbarian" view or scheme, merely as a shorthand. On the teachings of Ibn "Arabí and his school refer to Chittick, Sufi Path and Self-Disclosure of God, and Addas.

9. In a recent article in the Journal of Bahá'i Studies, Keven Brown has argued that the Bahá'í writings consistently present wáhidíyya as a station distinct and separate from the Essence of God (13). See also Saiedi 85.

10. I do not mean to suggest here that Ibn 'Arabí and his followers make no place for the Manifestation of God in their theories of cosmogony. On the contrary, Ibn 'Arabí frequently describes the Perfect or Universal Man, a figure that in some respects corresponds to the Bahá'í concept of the Manifestation of God, as the agent and purpose of creation. Indeed, both Akbarian and Bahá'í doctrines of cosmogony are rich and varied, and neither can be reduced to the concepts of fayd-i-aqdas and fayd-i-muqaddas. In this connection, it should be noted that Ibn 'Arabí's usage of terminology such as 'alam al-amr ("World of Command"), has entered Bahá'í vocabulary as the term for the intermediate realm occupied by the Manifestations of God, together with al-ghayb ("the Unseen") and 'alam al-khalq ("World of Creation") (Harris 48). Corbin's (and Izutsu's) simple division of Ibn "Arabí's theory of cosmogony into two stages, occuring in the "world of Mystery" and the "phenomenal world" respectively, therefore may be misleading. However, "Abdu'l-Bahá does attribute to "the mass of the Súfís" the belief in only two things- "God and the creature"-in opposition to the teaching of the Prophets that there are three worlds (295). For further discussion of the role of the Perfect Man in Ibn "Arabí's cosmology, see Takeshita, "The Homo Imago Dei Motif" and "The Theory of the Perfect Man"; Chittick, Sufi Path, SelfDisclosure of God, and "Five Divine Presences." For a discussion of the relationship between the Bahá'í concept of the Manifestation of God and the Sufi Perfect Man, see Saiedi 77-78.

11. With thanks to Khazeh Fananapazir for these references.

12. See Brown 9. Saiedi discusses the relativity of several different categorizations of the divine worlds that are found in the Bahá'í writings (96-97).

\section{Works Cited}

'Abdu'l-Bahá Some Answered Questions. Comp. and trans. Laura Clifford Barney. 4th ed. Wilmette, Ill.: Bahá'í Publishing Trust, 1981.

Addas, Claude. Quest for the Red Sulfur: The Life of Ibn 'Arabi. Trans. Peter Kingsley. Cambridge: Islamic Texts Society, 1993. 
Bahá'u'lláh. Epistle to the Son of the Wolf. Trans. Shoghi Effendi. Wilmette, Ill.: Bahá'i Publishing Trust, 1979. . Gleanings from the Writings of Bahá'u'lláh. Wilmette, Ill.: Bahá'í Publishing Trust, 1976.

. The Kitáb-i-Íqán: The Book of Certitude. Trans. Shoghi Effendi. London: Bahá'í Publishing Trust, 1982.

Black, D. L. “Al-Farabi.” Nasr and Leaman 1:178-97.

Brown, Keven. “'Abdu'l-Bahá's Response to the Doctrine of the Unity of Existence.” Journal of Bahá'i Studies 11.3/4 (2001): 1-24.

Chittick, William C. “The Five Divine Presences: From al-Qunawi to al-Qaysari.” Muslim World 72 (1982): 10728.

- The Self-Disclosure of God: Principles of Ibn al- 'Arabi's Cosmology. Albany: State University of New York Press, 1998.

- The Sufi Path of Knowledge: Ibn al- 'Arabi’s Metaphysics of Imagination. Albany: State University of New York Press, 1989.

Corbin, Henry. Creative Imagination in the Súfism of Ibn 'Arabí. Trans. Ralph Manheim. Princeton: Princeton University Press, 1969.

Dunbar, Hooper. A Companion to the Study of the Kitáb-i-Íqán. Oxford: George Ronald, 1998.

Genequand C. "Metaphysics." Nasr and Leaman 2:783-801.

Goodman, L. E. “Muhammad ibn Zakariyya' al Razi.” Nasr and Leaman 1:198-215.

Harris, Rabia Terri. “Sufi Terminology: Ibn ‘Arabi’s al-Istilâh al-Sûfiyyah.” Journal of the Muhyiddin Ibn 'Arabi Society 3 (1984): 27-54.

Ibn ‘Arabí, Muhyi’d-Din. Kernel of the Kernel. Trans. Ismail Hakki Bursevi. Beshara Publications, n. d.

Izutsu, Toshihiko. Sufism and Taoism: A Comparative Study of Key Philosophical Concepts. Berkeley: University of California Press, 1983.

Momen, Moojan. “'Abdu'l-Bahá's Commentary on the Islamic Tradition: 'I Was a Hidden Treasure . . ' Bahá'í Studies Bulletin 3.4 (1985): 4-37.

Nabíl-i-A'z. am (Muhammad-i-Zarandí). The Dawn-Breakers: Nabíl's Narrative of the Early Days of the Bahá'í Revelation. Trans. and ed. Shoghi Effendi. Wilmette, Ill.: Bahá'í Publishing Trust, 1974.

Nasr, Seyyed Hossein, and Oliver Leaman, eds. History of Islamic Philosophy. London: Routledge, 1998.

Netton, Ian Richard. Alláh Transcendent: Studies in the Structure and Semiotics of Islamic Philosophy, Theology, and Cosmology. Surrey: Curzon Press, 1989.

. "The Brethren of Purity (Ikhwan al-Safa')." Nasr and Leaman 1:220-30.

Saiedi, Nader. Logos and Civilization: Spirit, History, and Order in the Writings of Bahá'u'lláh. Bethesda: University Press of Maryland, 2000.

Shoghi Effendi. God Passes By. Wilmette, Ill.: Bahá'í Publishing Trust, 1995.

Takeshita, Masataka. "The Homo Imago Dei Motif and the Anthropocentric Metaphysics of Ibn 'Arabi in the Insha al-dawa'ir." Orient 18 (1982): 111-28.

"The Theory of the Perfect Man in Ibn 'Arabi’s Fusus al-hikam.” Orient 18 (1983): 87-102. 